\title{
Micronutrients Intake Status Between Risk and Non-Risk Anemia Groups Among University Students in Indonesia
}

\author{
Desi Nurmilah ${ }^{1}$, Arif Sabta Aji ${ }^{1,2}$, Siti Helmiyati ${ }^{3}$, Esti Nurwanti ${ }^{4}$ \\ ${ }^{1}$ Department of Nutrition, Universitas Alma Ata, Yogyakarta, Indonesia \\ ${ }^{2}$ Graduate School of Public Health, Universitas Alma Ata, Yogyakarta, Indonesia \\ ${ }^{3}$ Department of Nutrition, Universitas Gajah Mada, Yogyakarta, Indonesia \\ ${ }^{4}$ Department of Nutrition, Faculty of Health Sciences, Universitas Pembangunan Nasional Veteran \\ Jakarta \\ Correspondence:sabtaaji@almaata.ac.id.
}

\begin{abstract}
Anemia status is one of the public health problems at both global and Indonesia. The prevalence of anemia was found higher in the women of reproductive age. The prevalence in Special Region of Yogyakarta was even larger than the national average (34\% vs 21.7\%) for women of reproductive age group. Poor intake of micronutrient could be a major contributor to anemia. The aim of this study was to determine the difference of micronutrient intake among student with risk and no-risk anemia in the Alma Ata University. This cross-sectional study conducted from August to September 2020. Of 128 subjects was recruited and divided into two groups (64 risk anemia and 64 non-risk anemia group). The screening of anemia status was obtained by using self-assessment of clinical/physical questionnaires. Micronutrient intakes such as iron, folic acid, zinc, vitamin B6 and B12, cooper, and vitamin C were assessed by Semi Quantitative Food Frequency Questionnaire (SQ-FFQ). Independent T-test was created to analyze the difference of micronutrient intake in risk and non-risk anemia groups. In this study, there were significant differences in the intake of micronutrients such as iron $(\mathrm{p}<0.001)$, folic acid ( $p$ $<0.001)$, Zn ( $<<0.001)$, vitamin B6 (p<0.001), B12 ( $=0.008)$, and vitamin C $(\mathrm{p}<0.001)$ among students in risk and non-risk of anemia. However, there was no significant difference in $\mathrm{Cu}$ intake $(\mathrm{p}=0.975)$. In conclusion, lower micronutrient intake among students could lead to have higher anemia risk. Further studies with larger samples are required to confirm these findings.
\end{abstract}

Keywords: anemia, students, micronutrients intake, Indonesia 


\section{INTRODUCTION}

Anemia is one of the global public health problems which is found in many developing countries with the greatest consequences for health, social, and economic development. Anemia is well known as a disease was caused by low hemoglobin levels in the blood. Shariff et al (2018) found that the incidence of anemia during adolescent in Indonesia was high with $21.7 \%$ prevalence in national level. Special Region of Yogyakarta Province based on the age group 15-24 years has a prevalence of anemia in adolescent girls of $84.6 \%$, the age group $25-34$ years of $33.7 \%$, the age group $35-44$ years of $33.6 \%$ and the age group of $45-54$. year by $24 \%$. The prevalence of anemia in Special Region of Yogyakarta was quite high, which was dominated by pregnant women with $14.32 \%$ and the adolescent girls with 34\% (15). Kulonprogo Regency occupied the top position which had $73.8 \%$, followed by Bantul Regency (54.8\%), Yogyakarta City (35.2\%), Gunung Kidul (18.4\%), and Sleman $(18,4 \%)(8)$.

Based on the age category according to the definition of the Indonesian Minister of Health in 2010, students are included in the adult age range of $20-45$ years. In fact, the age of students was the final age from adolescence to adulthood or is a transitional age (20-24 years). Female students were prone to suffer fromanemia and it is proven that female students are more at risk of suffering from anemia than male students (12). This condition if continue for the next level of lifescycle will contribute to have higher anemia risk during pregnancy for them. Inadequate diet to maintain their appearance, misunderstanding of nutrition, excessive preference for certain foods, menstruation cycle were the risk of the occurrence of anemia. In addition, the high prevalence of anemia among adolescent girls in Indonesia can be a risk factor for anemia in adulthood and pregnancy $(23,16,25)$. Another study found that the important of lowering anemia prevalence in Indonesia will improve the maternal and child health, and the future of Indonesia's generation. Indonesia still needs big effort due to $48.90 \%$ of anemia case rates in the Indnoseia's pregnant women, moreover in other provinces could reach $61.90 \%(8,5)$.

The most common cause of anemia is deficiency of one or more nutrients, including iron (Fe), vitamin B12, folic acid, vitamin $\mathrm{B} 6$, vitamin $\mathrm{C}$, zinc $(\mathrm{Zn})$, and copper $(\mathrm{Cu})$. These nutrients play an important role in helping the body to produce and help absorb hemoglobin in the body. Micronutrients such as Iron, folic acid and vitamin B12 which are needed for the formation of Hemoglobin. Iron is an important substance in hemoglobin besides globin protein. Lack of folic acid can cause abnormalities that result in the appearance 
of blood cells with abnormal shapes and sizes (10). Vitamin B12 has a function that is closely related to folate. Vitamin B12 is needed by folic acid to become its active form (24). However, vitamin C functions to help increase the absorption of non-heme iron by up to 4 times (22). Lack of zinc intake indirectly affects iron metabolism because zinc acts as a cofactor in the retinol oxidation reaction. Low plasma retinol concentrations are associated with decreased iron plasma as well as decreased hemoglobin. Vitamin B6 is needed in protein metabolism which is also required for heme synthesis in the formation of hemoglobin. Copper is also associated with the iron oxidation for the formation of hemoglobin (24). All these micronutrients as important as macronutrients to maintain women health and prevent the complication during the pregnancy, a life cycle for women childbearing age $(2,4,3,9,14,20)$. Furthermore, the aim of this study was to identify whether micronutrient intake status affect the risk of anemia among University female students in the Alma Ata University, Yogyakarta.

\section{MATERIAL AND METHODS}

\section{Study design}

This study was a cross-sectional study design which was conducted in August-September 2020 in Alma Ata University. Alma Ata University is one of the private universities in Bantul, Special Region Yogyakarta, Indonesia where the area has the highest prevalence of anemia cases of adolescent girls in D.I Yogyakarta Province (15). Data collections were collected by telephone call interviews and using Google Forms as replace the questionnaire paper-based and to avoid the direct contact between researchers and subjects due to the current pandemic conditions. Female students were recruited to be the subjects of this research. This study identified whether there was a relationship between food intake and risk of anemia. Micronutrient intake was seen through the previously validated SemiQuantitative Food Frequency Questionnaire (SQ-FFQ) (29). The nutritional intake seen such as $\mathrm{Fe}$, folic acid, zinc, $\mathrm{Cu}$, vitamin $\mathrm{B} 6$, and vitamin $\mathrm{C}$. The choice of micronutrients was chosen because it has been shown to be associated with the risk of anemia caused by nutrient deficiency (10).

\section{Study subjects}

The subjects of this study were students of Alma Ata University. The selection of the sampling method in this study using consecutive sampling method. The selection of the subjects was adjusted to the inclusion and exclusion criteria. The students were selected if (1) Students who have more than 19 years old; (2) Active 
students' status at Alma Ata University; and (3) Had a good health. However, students who had the criteria of being pregnant and been menstruating or in their period during the interview process and data collection will be excluded. A total of 128 subjects were selected to participate in this study.

\section{Data collection}

Students were divided into two groups, the case and control groups, with an equal number of 64 students per group. The selection of case and control groups was based on the anemia risk analysis obtained from filling out the previously validated anemia screening questionnaire (17). Anemia screening questionnaire will separate those who were at risk of anemia (case group) and those who were not at risk of anemia (control group). Anemia screening data was conducted independently or self-assessment by the subjects. This screening questionnaire found at the physical or clinical symptoms of anemia. The screening questionnaire consisted of 8 closed question groups (Yes or No). These questions include (1) Are the lower eyelids pale?; (2) Is the tongue pale?; (3) Are the nails pale in color?; (4) Do finger nails get damaged easily?; (5) Do you often experience lightheadedness?; (6) Do you often experience dizziness?; (7) Do you often feel weak?; and (8) Do you often feel tired?. Scoring analysis was done for each question which showed that the physical or clinical symptoms of anemic indicators. The scoring calculation analysis was performed to determine whether the subjects were in the anemia risk group $($ score $\geq 3$ ) or not-risk anemia ( score $<3$ ). The data that has been obtained were analyzed to see the difference in the average intake of micronutrients among students who are at risk of anemia and who are not at risk of anemia.

Dietary assessment for micronutrients such as intake of Iron, Zinc, vitamin $\mathrm{C}$, vitamin $\mathrm{B} 6$, vitamin $\mathrm{B} 12$, Copper, and folic acid were obtained using the Semi-Quantitative Food Frequency Questionnaire (SQ-FFQ). Questions in the SQ-FFQ were included to the type and amount of their food consumption in the last three months. The trained enumerators (nutritionists) were selected to conduct SQFFQ interviews to the subjects. Interviews were conducted by telephone or online call using a virtual meeting application. The result of the SQ-FFQ was the average intake of micronutrients conuspmtion. The questionnaire had previously validated and modified with the types of local food ingredients available in Bantul, Special Regions of Yogyakarta. Daily vitamin and mineral supplement consumption data were also asked to identify additional intake of vitamins and minerals outside of food. Determination of the status of micronutrient 
intake was obtained by comparing the amount of daily micronutrient intake of research subjects with references to the Recommended Dietary Allowance (RDA) held by Indonesia in 2019 (19). Data for the category of micronutrient intake status is presented in Table 1.

Table 1

Micronutrient Intake-related Anemia Status

\begin{tabular}{lcc}
\hline \multicolumn{1}{c}{ Variables } & Inadequate & Adequate \\
\hline Iron $(\mathrm{Fe}), \mathrm{mg}$ & $<18$ & $\geq 18$ \\
\hline $\begin{array}{l}\text { Folic acid, } \\
\text { mcg }\end{array}$ & $<400$ & $\geq 400$ \\
\hline $\begin{array}{l}\text { Vitamin B6, } \\
\text { mg }\end{array}$ & $<1.3$ & $\geq 1.3$ \\
\hline $\begin{array}{l}\text { Vitamin } \mathrm{B} 12, \\
\text { mcg }\end{array}$ & $<4$ & $\geq 4$ \\
\hline $\begin{array}{l}\text { Copper }(\mathrm{Cu}), \\
\text { mg }\end{array}$ & $<0.9$ & $\geq 0.9$ \\
\hline $\begin{array}{l}\text { Vitamin C, } \\
\text { mg }\end{array}$ & $<75$ & $\geq 75$ \\
\hline Zinc $(\mathrm{Zn}), \mathrm{mg}$ & $<8$ & $\geq 8$
\end{tabular}

Indonesia Recommended Dietary Allowance (RDA) as reference for the detemining of micronutrients intake status. mcg, microgram

\section{Statistical analysis}

Continuous data will be presented with mean and standard deviation (SD) and categorical data will be presented as numbers and percentages (\%). To determine the difference in the average micronutrient intake in the control and case groups, the statistical test was performed by independent t-test as the distribution of the variables were normal with KolmogorovSmirnov test. Data were analyzed using
SPSS version 20 and Nutrisurvey. Data having a $\mathrm{p}$-value $<0.05$ were stated as significant results.

\section{Ethical clearance}

This study was conducted according to the guidelines laid down in the Declaration of Helsinki and all procedures involving research study subjects were approved by the Ethical Committee of Alma Ata University (KE/AA/VIII/10233/EC/2020). Data were collected with the consent of research subjects who previously given online informed consent.

\section{RESULTS}

\section{Subject's characteristics}

Tabel 2 showed that the majority of subjects were students from the health sciences faculty (85.94\%), lived at home $(46.09 \%)$, and the majority living allowance of the subjects was $<$ IDR 1,000 $(56.25 \%)$. The results of the risk anemia screening process carried out by selfassessment to determine the risk and nonrisk anemia groups showed that the percentage of the students at risk of anemia among non-health sciences students was higher $(66.60 \%)$ compared to health students $(47.70 \%)$.

Table 2: Subject's characteristics

\begin{tabular}{lcc}
\hline \multicolumn{1}{c}{ Characteristics } & $\mathbf{n}$ & $\mathbf{\%}$ \\
\hline \multirow{2}{*}{ Faculty } & 110 & 85.94 \\
\hline
\end{tabular}




\begin{tabular}{|c|c|c|c|}
\hline- & $\begin{array}{l}\text { Health } \\
\text { sciences }\end{array}$ & 18 & 14.06 \\
\hline \multirow[t]{2}{*}{ - } & Non-health & 59 & 46.09 \\
\hline & sciences & 57 & 44.53 \\
\hline \multicolumn{2}{|l|}{ Living } & 12 & 9.38 \\
\hline \multicolumn{4}{|c|}{ - House } \\
\hline & Indekos & 56 & 43.75 \\
\hline- & Dormitory & 72 & 56.25 \\
\hline \multicolumn{4}{|c|}{ Monthly allowance } \\
\hline \multicolumn{4}{|c|}{$-\quad \geq 1,000 \mathrm{IDR}$} \\
\hline \multicolumn{4}{|c|}{$-\quad<1,000 \mathrm{IDR}$} \\
\hline \multicolumn{4}{|c|}{ Screening a nemia } \\
\hline \multirow{4}{*}{-} & Risk of & $\begin{array}{l}04 \\
64\end{array}$ & 50.0 \\
\hline & anemia & & \\
\hline & Non-risk of & 12 & 47.70 \\
\hline & anemia & 52 & 66.60 \\
\hline \multicolumn{4}{|c|}{$\begin{array}{l}\text { Anemia risk based on } \\
\text { their fa culty }\end{array}$} \\
\hline \multicolumn{4}{|c|}{ - Health } \\
\hline \multicolumn{4}{|c|}{$\begin{array}{l}\text { sciences } \\
\text { - } \quad \text { Non-health }\end{array}$} \\
\hline & $\begin{array}{l}\text { Non-health } \\
\text { sciences }\end{array}$ & & \\
\hline
\end{tabular}

\section{Micronutrient intake status}

The data of micronutrients intake from SQFFQ were compared to the adequacy of micronutrient consumption based on the guideline of Recommended Dietary Allowance (RDA) 2019. The micronutrient intake of selected subjects in this study was obtained based on the processing data from SQ-FFQ and of nutritional survey software to determine how much the amount of them. Table 3 presented that the majority of micronutrient intake in students at risk oand non-risk of anemia had a lower average intake compared to the RDA guidelines based on their age and gender. These low statuses of micronutrient intake were iron, folic acid, zinc, copper, vitamin B6, and vitamin B12, except vitamin C in this study.
Table 3: The average of the subject's micronutrients intake

\begin{tabular}{lrrrc}
\hline Variables & Mean & Min & Max & Status \\
\hline Fe $(\mathrm{mg})$ & 9.87 & 3.30 & 16.40 & Inadequate \\
Folic acid & 174.98 & 52.80 & 293.30 & Inadequate \\
(mcg) & & & & \\
$\mathrm{Zn}(\mathrm{mg})$ & 6.11 & 2.00 & 12.00 & Inadequate \\
$\mathrm{Cu}(\mathrm{mg})$ & 0.70 & 0.20 & 1.20 & Inadequate \\
Vitamin & 1.13 & 0.30 & 2.10 & Inadequate \\
B6 (mg) & & & & \\
Vitamin & 1.42 & 0.20 & 2.50 & Inadequate \\
B12 (mcg) & & & & \\
Vitamin C & 92.04 & 3.50 & 200.00 & Adequate \\
(mg) & & & & \\
\hline
\end{tabular}

Micronutrients intake status was determined by RDA 2019. Mcg, microgram; Fe, iron; Zn. Zinc; $\mathrm{Cu}$, copper.

\section{Association between micronutrient intake levels and risk and non-risk anemia group}

Table 4 showed that the intake of micronutrients in the students at risk of anemia group had an average intake lower than students who were not at risk of anemia. Unbalanced and inadequate food intake can be a risk factor for anemia, especially in the intake of micronutrients in this case iron $(\mathrm{Fe})$, folic acid, zinc $(\mathrm{Zn})$, vitamins B6, B12 and vitamin C (35).

Table 4: Average intake of micronutrients among students with risk and non-risk anemia

\begin{tabular}{|c|c|c|c|c|}
\hline \multirow[t]{2}{*}{ Variables } & \multicolumn{2}{|c|}{$\begin{array}{l}\text { Risk of } \\
\text { Anemia }\end{array}$} & \multicolumn{2}{|c|}{$\begin{array}{c}\text { Non-risk of } \\
\text { anemia }\end{array}$} \\
\hline & Mean & \pm SD & Mean & \pm SD \\
\hline Fe (mg) & 7.659 & 1.824 & 12.082 & 2.037 \\
\hline $\begin{array}{l}\text { Folic acid } \\
(\mathrm{mcg})\end{array}$ & 1.410 & 45.925 & 2.088 & 54.042 \\
\hline $\mathrm{Zn}(\mathrm{mg})$ & 4.646 & 1.439 & 7.565 & 2.251 \\
\hline $\mathrm{Cu}(\mathrm{mg})$ & 0.701 & 0.241 & 0.700 & 0.308 \\
\hline $\begin{array}{l}\text { Vitamin } \\
\text { B6 (mg) }\end{array}$ & 0.984 & 0.422 & 1.281 & 0.424 \\
\hline $\begin{array}{l}\text { Vitamin } \\
\text { B12 } \\
(\mathrm{mcg})\end{array}$ & 1.289 & 0.522 & 1.559 & 0.613 \\
\hline $\begin{array}{l}\text { Vitamin } \\
\mathrm{C}(\mathrm{mg})\end{array}$ & 74.30 & 49.377 & 1.097 & 44.887 \\
\hline \multirow{2}{*}{ Variables } & Mean & \multicolumn{2}{|c|}{$95 \% \mathrm{CI}$} & $\mathbf{P}$ \\
\hline & Difference & Lower & Upper & Value \\
\hline Fe (mg) & -4.423 & -5.099 & -3.746 & $<0.001$ \\
\hline $\begin{array}{l}\text { Folic acid } \\
(\mathrm{mcg})\end{array}$ & -67.785 & 85.329 & $50 . \overline{2} 42$ & $<0.001$ \\
\hline $\mathrm{Zn}(\mathrm{mg})$ & -2.920 & -3.581 & -2.259 & $<0.001$ \\
\hline $\mathrm{Cu}(\mathrm{mg})$ & 0.001 & -0.095 & 0.984 & 0,975 \\
\hline
\end{tabular}




\begin{tabular}{|c|c|c|c|c|}
\hline $\begin{array}{l}\text { Vitamin } \\
\text { B6 (mg) }\end{array}$ & -0.296 & -0.444 & -0.148 & $<0.001$ \\
\hline $\begin{array}{l}\text { Vitamin } \\
\text { B12 } \\
(\mathrm{mcg})\end{array}$ & -0.270 & -0.469 & -0.071 & 0,008 \\
\hline $\begin{array}{l}\text { Vitamin } \\
\mathrm{C}(\mathrm{mg})\end{array}$ & -35.462 & $\begin{array}{c}- \\
51.962\end{array}$ & $\begin{array}{c}- \\
18.962\end{array}$ & $<0.001$ \\
\hline
\end{tabular}

DISCUSSION

\section{Association between micronutrient intake status between risk and non-risk anemia group}

Iron is the main component that important in the formation of blood (hemopoiesis) especially in the formation of hemoglobin molecules. Iron stores in the body (ferritin and hemosiderin) are found in the liver, spleen and bone marrow. If the amount of iron in the form of deposits is sufficient, the need for the formation of red blood cells in the bone marrow will always be fulfilled. However, if iron stores are reduced and the amount of iron obtained from food is less than what is needed, there will be an imbalance of iron in the body, which in turn will cause iron nutritional anemia (28).

Based on the results of the analysis, it showed that there was a significant difference in the intake of micronutrient iron $(\mathrm{Fe})$ in students at risk of anemia and non-risk of anemia at Alma Ata University with a $p$ value $<0.001$. These results are in line with research conducted on young women in 2019 which states that there were significant differences in the iron intake (7). The results of the analysis of this study also support the previous research which stated that there was a relationship between iron (Fe) intake and hemoglobin levels and the incidence of anemia (1). The casuality of the high anemia prevalence in women was due to various factors, especially insufficient iron consumption and low iron absorption and $25 \%$ of what causes anemia in adolescent girls was due to iron deficiency (7). In addition, it can also cause by execcive and not helped bleeding, malaria, worm infection, but more than $50 \%$ of cases of anemia worldwide are directly caused by a lack of iron intake (26).

There were significant differences in the intake of folic acid micronutrients in students at risk of anemia and no risk of anemia at Alma Ata University. The results of this study support the research conducted in the women childbearing age group in 2012 which stated that there was a significant correlation between folic acid intake and hemoglobin levels and anemia with the anemia group having a lower average consumption of folic acid (18). The results of this study were in line with research by Thompson et al which states that the intake of protein, folate, vitamin $\mathrm{B} 12$, and iron in anemic elderly women is lower than that in elderly women who are not anemic (33). This proves that folic acid was involved in the metabolism of several amino acids, one of which is glycine as the main ingredient in heme synthesis. Folate 
was needed for the formation of red blood cells and white blood cells in bone marrow and maturation. Folate acts as a single carbon carrier in the formation of heme. After further analysis, the non-anemic group had a lower mean intake of folic acid and the amount of folic acid consumption correlated significantly with hemoglobin levels (21).

This study showed that there was no significant difference in $\mathrm{Cu}$ micronutrient intake in students at risk of anemia and no risk of anemia at Alma Ata University. The results of this study were not in line with the study from Cendani and Murbawani (2011) which states that there is a relationship between copper intake and hemoglobin levels. Research on anemic adolescent girls in 2019 stated that there was a significant difference between $\mathrm{Cu}$ intake in anemic and non-anemic adolescents (7). Copper is a micronutrient that is widely needed by humans and animals which is used for organ function and for metabolic processes such as hemoglobin synthesis and for iron oxidation. Copper has a role in the body, namely as an enzyme that will be involved in the function of the cytochrome chain in the oxidation process in mitochondria, copper also plays a role in helping iron absorption, helps stimulate hemoglobin synthesis and releases iron stores from ferritin in the liver (6). The absence of a significant difference between $\mathrm{Cu}$ intake in students at risk of anemia and no risk could be caused because the two groups consumed almost the same amount of $\mathrm{Cu}$ source foods. Respondents in this study mostly consumed food ingredients such as tempeh, tofu and chicken meat.

In this study, the results showed that there was a significant difference in the intake of vitamin B6 in students at risk of anemia and no risk of anemia at Alma Ata University. The results of this study were in line with research conducted on young women in 2011 which states that there is a significant relationship between vitamin B6 intake and hemoglobin levels, which means that the higher the five intake, the greater the value of hemoglobin levels obtained. This was consistent with the results of a study on adult women in China which showed an association between vitamin B6 deficiency and the incidence of anemia (11). Further analysis showed that the students at risk of anemia had a lower average consumption of vitamin B6. In terms of quantity, these results were in line with the function theory of vitamin B6 that together with riboflavin, vitamin B6 also acts as an enzyme cofactor in the heme biosynthesis process. The presence of these two vitamins must be sufficient for hemoglobin synthesis to be functioned properly, when its availability in the body was low it will interfere with the globin synthesis, so that the iron was trapped in 
ferritin and was not available for erythropoesis (6). This condition affects when the body was deficient in vitamin B6, the protein metabolism will be disrupted, as well as the formation of $\mathrm{Hb}$.

The difference of vitamin B12 intake occurred because most of the groups at risk of anemia consumed food sources of vitamin B12 which was animal products such as chicken eggs, fish and red meat, less than the group not at risk of anemia. The results of the analysis of this study also support previous research on adolescents in 2016 which stated that there was a significant relationship between vitamin B12 intake and hemoglobin levels and anemia (30). After analyzing the results of the research analysis, the group at risk of anemia had an average consumption of vitamin B12 that was lower. This showed that low intake of vitamin B12 in respondents atrisk of anemia is a risk factor for anemia. The main function of vitamin $\mathrm{B} 12$ is to increase hemoglobin levels because the nutrients in the body interact with each other. Vitamin B12 had a role in various metabolisms as a coenzyme. Vitamin B12 deficiency and iron deficiency often co-occur when animal intake is low. Deficiency of vitamin B12 increases the loss of iron in the intestine and interferes with the absorption and mobilization of intracellular iron so that it is possible to interfere with globin synthesis, then the iron is trapped in ferritin and is not available for erythropoesis. Vitamin B12 is not damaged much during the cooking process. Vitamin B12 and its metabolites are mainly stored in the form of Flavine Adenine Diphosphate (FAD) which represents $70-90 \%$ of the vitamin (27).

The results of the analysis of this study supported the previous research on adolescents in 2016 which states that there was a significant relationship between vitamin $\mathrm{C}$ intake and hemoglobin levels and anemia (30). The results of this study were also in line with research conducted on young women in 2015 which stated that there was a significant relationship between vitamin intake (31). After further analysis, the group at risk of anemia had a lower mean intake of vitamin $\mathrm{C}$ and the amount of vitamin $\mathrm{C}$ intake was significantly correlated with hemoglobin levels. This showed that good vitamin $\mathrm{C}$ intake will increase hemoglobin levels because the micronutrients in the body interact with each other. The function of vitamin $\mathrm{C}$ in biological systems was as a reducing compound, for example reducing iron from ferrous $(\mathrm{Fe} 3+)$ to ferrous $(\mathrm{Fe} 2+)$ so that it is easily absorbed by the intestine during iron metabolism (36). Vitamin $\mathrm{C}$ involved in the mobilization of iron stores, especially hemosiderin in the spleen and absorption of iron in the non-heme form can be increased fourfold in the presence of vitamin $\mathrm{C}$. 
Vitamin $\mathrm{C}$ easily absorbed with an absorption rate of $90 \%$ for consumption of 20-120 mg daily. Therefore, even though the intake of vitamin $\mathrm{C}$ was less than the body's needs, itcan still meet from its stores so that it can be benefited during the hemoglobin synthesis (13).

\section{CONCLUSION AND RECOMMENDATION}

There were significant impacts on iron (Fe), folic acid, $\mathrm{Zn}$, vitamin B6, vitamin $\mathrm{B} 12$, and vitamin $\mathrm{C}$, yet no association in the copper $(\mathrm{Cu})$ intake status among female students in the risk and nonrisk of anemia at Alma Ata University. Only vitamin C intake among female students who had adequate intake status. However, most of them had inadequate status intake either in the risk and non-risk group of anemia.

Adequate of micronutrient-related anemia status should be considered to promote in the form of education to further increasing the intake both in quality and quantity, especially in the micronutrients to increase hemoglobin levels and prevent anemia status especially for students who are at risk of anemia. This research was conducted using an independent measurement method or self assessment, so that it can cause analysis bias in the results of determining the risk of anemia and the status of micronutrient intake. Therefore, further researchs are warrant to confirm these findings.

\section{ACKNOWLEDGMENT}

The authors thank to all the subjects who have participated in this study. This work was supported by the Universitas Alma Ata. The authors declare no conflict of interest.

\section{REFERENCES}

1. Abbaspour, N., Hurrell, R., \& Kelishadi, R. (2014). Review on iron and its importance for human health. Journal of research in medical sciences: the official journal of Isfahan University of Medical Sciences, 19(2), 164-174.

2. Aji, A.S., Erwinda, E., Rasyid, R., Yusrawati, Y., Malik, S.G., Alathari, B., Lovegrove, J.A., Lipoeto, N.I., Vimaleswaran, K.S. (2020a). A genetic approach to study the relationship between maternal Vitamin D status and newbom anthropometry measurements: the Vitamin D pregnant mother (VDPM) cohort study. J Diabetes Metab Disord 19, 91-103. https://doi.org/10.1007/s40200-01900480-5.

3. Aji, A.S., Erwinda, E., Yusrawati, Y., Malik, S.G., Lipoeto, N.I. (2019a). Vitamin D deficiency status and its related risk factors during early pregnancy: a cross-sectional study of pregnant Minangkabau women, Indonesia. BMC Pregnancy Childbirth 19, 183. https://doi.org/10.1186/s12884-0192341-4.

4. Aji, A.S., Yerizel, E., Desmawati, D., Lipoeto, N.I. (2019b). Low Maternal Vitamin D and Calcium Food Intake 
during Pregnancy Associated with Place of Residence: A CrossSectional Study in West Sumatran Women, Indonesia. Open Access Macedonian Journal of Medical Sciences 7, 2879-2885. https://doi.org/10.3889/oamjms.2019 .659 .

5. Aji, A.S., Yusrawati, Y., Malik, S.G., Lipoeto, N.I. (2020). Prevalence of anemia and factors associated with pregnant women in West Sumatra, Indonesia: Findings from VDPM Cohort Study. Jurnal Gizi dan Dietetik Indonesia (Indonesian Journal of Nutrition and Dietetics) 7 , 97-106.

https://doi.org/10.21927/ijnd.2019.7( 3).\%p.

6. Almatsier, S. (2009). Prinsip Dasar Ilmu Gizi. Jakarta : Gramedia Pustaka Utama.

7. Astuti, E Y. (2019). Perbedaan Asupan Mineral antara Remaja Putri yang Anemia dan Non Anemia di SDN Totosari I dan Tunggulsari I, II Surakarta [Skripsi]. Surakarta: Universitas Muhammadiyah Surakarta.

8. Badan Penelitian dan Pengembangan Kesehatan. (2019). Riset Kesehatan Dasar 2018. Jakarta : Kementerian Kesehatan RI.

9. Bardosono, S. (2016). Maternal Micronutrient Deficiency during the First Trimester among Indonesian Pregnant Women Living in Jakarta. JKI 4, 76-81. https://doi.org/10.23886/ejki.4.6281. 76-81.

10. Briawan, Dodik MCN. (2014). Anemia: Masalah Gizi pada Remaja Wanita. Jakarta: ECG.

11. Cendani, C., Murbawani, E.A., (2011). Asupan Mikronutrien, Kadar Hemoglobin dan Kesegaran Jasmani Remaja Putri. MEDIA MEDIKA INDONESIANA 45, 26-33.

12. Chibriyah, Rizka. (2017). Hubungan Pola Makan dan Aktivitas Fisik terhadap Kadar Hemoglobin Santriwati Pondok Pesantren AlMunawwir Krapyak Bantul [Skripsi]. Yogyakarta: Universitas 'Aisyiyah Yogyakarta.

13. Compounds, I. of M. (US) P. on D.A. and R., (2000). Vitamin C, Dietary Reference Intakes for Vitamin C, Vitamin E, Selenium, and Carotenoids. National Academies Press (US).

14. Christian, P., Stewart, C.P. (2010). Maternal micronutrient deficiency, fetal development, and the risk of chronic disease. J. Nutr. 140, 437445.

https://doi.org/10.3945/jn.109.11632 7

15. Dinas Kesehatan DI Yogyakarta. (2017). Profil Kesehatan Provinsi Daerah Istimewa Yogyakarta Tahun 2017. DI Yogyakarta: Dinas Kesehatan DI Yogyakarta.

16. Fadlillah, Siti. (2018). Faktor-Faktor yang Berhubungan dengan Kadar Hemoglobin $(\mathrm{Hb})$ Pada Mahasiswa Keperawatan Angkatan 2013 Universitas Respati Yogyakarta [Skripsi]. Yogyakarta: Universitas Respati Yogyakarta.

17. Hidayati, I.Z; Astutik, E; Firdaus, H; dan Ayodiya, G. (2019). Penilaian Uji Validitas Instrumen Skrining Anemia Pada Siswa Madrasah Aliyah Islamic Center Baiturahman Banyuwangi. MaKMA: 2(3) : 48-58.

18. Işık Balcı, Y., Karabulut, A., Gürses, D., \& Ethem Çövüt, I. (2012). Prevalence and Risk Factors of Anemia among Adolescents in Denizli, Turkey. Iranian journal of pediatrics, 22(1), 77-81.

19. Kementrian Kesehatan RI. (2019). Angka Kecukupan Gizi (AKG) 2019. Jakarta: Kementrian Kesehatan RI

20. Lipoeto, N.I., Aji, A.S., Faradila, F., Ayudia, F., Sukma, N.P., (2018). Maternal vitamin $\mathrm{D}$ intake and serum 25-hydroxyvitamin D $(25(\mathrm{OH}) \mathrm{D})$ levels associated with blood pressure: 
A cross-sectional study in Padang, West Sumatra. MJN 24, 407-415.

21. Locasale J. W. (2013). Serine, glycine and one-carbon units: cancer metabolism in full circle. Nature reviews. Cancer, 13(8), 572-583. https://doi.org/10.1038/nrc3557.

22. Novitasari, Suci. (2014). Hubungan Tingkat Asupan Protein, Zat Besi, Vitamin $\mathrm{C}$ dan Seng dengan Kadar Hemoglobin pada Remaja Putri di SMA Batik 1 Surakarta [Skripsi]. Surakarta: Universitas Muhammadiyah Surakarta.

23. Nuraeni, Rizki. (2015). Hubungan Pola Diet dengan Kejadian Anemia pada Mahasiswa Kebidanan D IV Stikes 'Aisyiyah Yogyakarta. [Skripsi]. Yogyakarta: Sekolah Tinggi Ilmu Kesehatan 'Aisyiyah Yogyakarta.

24. Patimah, Sitti; Veni, Hadju; Burhanuddin, Bahar; dan Zulfikifli, Abdullah. (2011). Pola Konsumsi dan Kadar Hemoglobin pada Ibu Hamil di Kabupaten Maros Sulawesi Selatan. Jurnal Makara Kesehatan. 15(10): 31-36.

25. Prastyani, E L. (2017). Hubungan antara Pola makan dengan Kejadian Anemia pada Remaja Putri di SMA Kabupaten Bantul [Skrippsi]. Yogykarta: Universitas Alma Ata.

26. Reinke S, Taylor WR, Duda GN, von Haehling S, Reinke P, Volk HD, Anker SD, Doehner W. (2010). Absolute and functional iron deficiency in professional athletes during training and recovery. Int $\mathrm{J}$ Cardiol 156: 186-191.

27. Sahana, O.N., Sumarmi, S. (2015). Hubungan Asupan Mikronutrien Dengan Kadar Hemoglobin Pada Wanita Usia Subur (WUS). Media Gizi Indonesia 10, 184-191. https://doi.org/10.20473/mgi.v10i2.1 84-191.

28. Shvartsman, M., Bilican, S. \& Lancrin, C. (2019). Iron deficiency disrupts embryonic haematopoiesis but not the endothelial to haematopoietic transition. Sci Rep 9, 6414.

https://doi.org/10.1038/s41598-01942765-y

29. Sirajuddin, surmita, dan astute trina. (2018). Bahan Ajar Gizi ed. 2018: Survey Konsumsi Pangan. Jakarta: Badan Pengembangan dan Pemberdayaan SUmber Daya Manusia Kesehatan, Kementrian Kesehatan RI.

30. Siallgan, D; Swamilaksita, P D dan Angkasa, D. (2016). Pengaruh Asupan Fe, Vitamin A, Vitamin B12, dan Vitamin $\mathrm{C}$ terhadap Kadar Hemoglobin pada Remaja Vegan. Jurnal Gizi Klinik Indonesia: 13(2): 67-74

31. Pratiwi, Eka. (2015). Faktor-Faktor yang Mempengaruhi Anemia [Skripsi]. Jakarta: Universitas Islam Negeri Syarif Hidayatullah.

32. Shariff, S.A; dan Akbar, Nurlina. (2018). Hubungan antara Status Gizi dan Pola Menstruasi dengan Kejadian Anemia pada Mhasiswi Prodi Kebidanan Universitas Muslim Indonesia. Window of Health. 1(1): 34-39.

33. Thomson CA, Stanaway J, Neuhouser ML, Snetselaar LG, Stefanick ML, Arendell L, Chen Z. (2011). Nutrient intake and Anemia Risk in the WHI Observational Study. J Am Diet Assoc: 111(4): 532;541.

34. Wicaksono, Teguh dan Noer, E R. (2018). Perbedaan Asupan Zat Gizi pada Lansia Anemia dan Non Anemia. Journal of Nutrition College: 2(3) : 358-363.

35. Zhang, Q., Qin, G., Liu, Z., Li, Z., Li, J., Varma, D. S., Wan, Q., Zhao, J., Min, X., Han, X., \& Liu, M. (2018). Dietary Balance Index-07 and the Risk of Anemia in Middle Aged and Elderly People in Southwest China: A Cross Sectional Study. Nutrients, 10(2), 162. https://doi.org/10.3390/nu10020162. 
36. Bakti. Hematologi Klinik Ringkas.

Jakarta : ECG; 2015. 